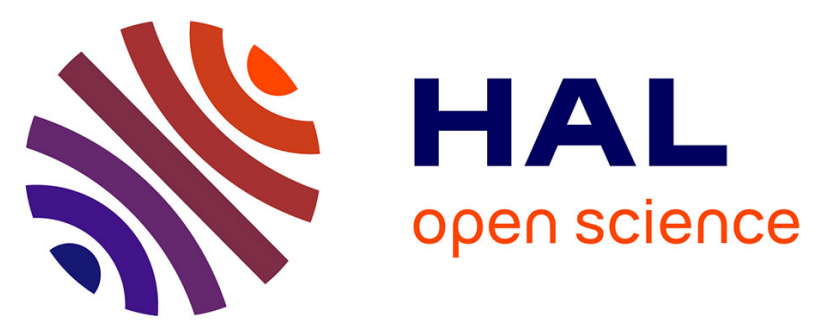

\title{
Antidepressant, Myorelaxant and Anti-Anxiety-Like Effects of Nauclea latifolia Smith (Rubiaceae) Roots Extract in Murine Models
}

Germain Sotoing Taïwe, Elisabeth Ngo Bum, Théophile Dimo, Emmanuel Talla, Norbert Weiss, Amadou Dawe, Clarisse Okomolo F. Moto, N. Sidiki, Paul Désiré Dzeufiet, Michel de Waard

\section{To cite this version:}

Germain Sotoing Taïwe, Elisabeth Ngo Bum, Théophile Dimo, Emmanuel Talla, Norbert Weiss, et al.. Antidepressant, Myorelaxant and Anti-Anxiety-Like Effects of Nauclea latifolia Smith (Rubiaceae) Roots Extract in Murine Models. International Journal of Pharmacology, 2010, 6 (4), pp.364-371. inserm-00644849

\section{HAL Id: inserm-00644849 https://www.hal.inserm.fr/inserm-00644849}

Submitted on 25 Nov 2011

HAL is a multi-disciplinary open access archive for the deposit and dissemination of scientific research documents, whether they are published or not. The documents may come from teaching and research institutions in France or abroad, or from public or private research centers.
L'archive ouverte pluridisciplinaire HAL, est destinée au dépôt et à la diffusion de documents scientifiques de niveau recherche, publiés ou non, émanant des établissements d'enseignement et de recherche français ou étrangers, des laboratoires publics ou privés. 
International Journal of Pharmacology 6(4): 364-371, 2010

ISSN 1811-7775

(C) 2010 Asian Network for Scientific Information

\title{
Antidepressant, Myorelaxant and Anti-Anxiety-Like Effects of Nauclea latifolia Smith (Rubiaceae) Roots Extract in Murine Models
}

\author{
${ }^{1,2}$ G.S. Taïwe, ${ }^{3}$ E. Ngo Bum, ${ }^{1}$ T. Dimo, ${ }^{4}$ E. Talla, ${ }^{2}$ N. Weiss, ${ }^{5}$ A. Dawe, \\ ${ }^{1}$ F.C.O. Moto, ${ }^{3}$ N. Sidiki, ${ }^{1}$ P.D. Dzeufiet and ${ }^{2}$ M. De Waard \\ ${ }^{1}$ Department of Animal Biology and Physiology, Faculty of Science, University of Yaoundé I, \\ P.O. Box 812, Yaoundé, Cameroon \\ ${ }^{2}$ INSERM U836, Calcium Channels, Functions and Pathologies, Grenoble Institute of Neurosciences, \\ Université Joseph Fourier, P.O. Box 170, 38042 Cedex 9, Grenoble, France \\ ${ }^{3}$ Department of Biological Sciences, \\ ${ }^{4}$ Department of Chemistry, Faculty of Science, University of Ngaoundéré, \\ P.O. Box 454, Ngaoundéré, Cameroon \\ ${ }^{5}$ Ecole Normale Supérieure, University of Maroua, P.O. Box 55, Maroua, Cameroon
}

\begin{abstract}
The neuropharmacological effects of the decoction of Nauclea latifolia Smith (Rubiaceae) roots were studied in mice. Different experimental models (forced swimming test, horizontal wire test and hole-board test) were used for detecting antidepressant, myorelaxant and anxiolytic properties. The results revealed that Nauclea latifolia induced a reduction of immobility, in a similar way to that of fluoxetine, along with a significant increase in the percentage of spent time in swimming behavior. Nauclea latifolia displayed a myorelaxant activity in the horizontal wire test. In the hole-board test, Nauclea latifolia significantly increased the number and duration of head-dips. In addition, anxiolytic-like properties of Nauclea latifolia were blocked by anxiogenic agents as examined in the hole-board test. This was the case for N-methyl- $\beta$-carboline-3carboxamide (FG7142), a partial inverse agonist at the benzodiazepine site of the GABA $_{\mathrm{A}}$ receptor complex, flumazenil (RO151788), a central benzodiazepine receptor antagonist and bicuculline, a light-sensitive competitive antagonist of $\mathrm{GABA}_{\mathrm{A}}$ receptors. These results suggest that Nauclea latifolia roots decoction possess antidepressant, myorelaxant and anti-anxiety-like properties in the models employed. The extracts might potentially act by GABAergic activation and/or by modulating the serotoninergic levels in the central nervous system. However, further studies were still required.
\end{abstract}

Key words: Nauclea latifolia, neuropharmacology, antidepressant, myorelaxant, anti-anxiety

\section{INTRODUCTION}

A growing number of herbal medicines are being introduced into psychiatric practice, many of which have comparable efficacy to prescription medications with lower side effects. This makes herbal therapies as desirable alternative treatment for severe depression and anxiety disorders. People from different regions of the world have used herbal medicines to alleviate affective disorders for many years. Medicinal plants exudates, gums, resins, etc., are used for the treatment of different diseases, including pain, neuralgia, dyspepsia and anorexia. An increasing number of herbal products have been introduced into psychiatric practice, as alternative or complementary medicines (Woode et al., 2010). Similarly, the therapeutic potential of a proving number of herbal medicines has been assessed in several animal models (Zhang, 2004). In fact, these models have contributed to the screening of new psychopharmacological tools and to the understanding of their biological activity (Buller and Legrand, 2001).

Nauclea latifolia Smith (Rubiaceae) is a shrub widely found in Cameroon. Different parts of the plant have been advocated in a variety of disease conditions. The roots have been reported to possess diaphoretic and alterative actions for use in pyrexia-induced cold

Corresponding Author: Germain Sotoing Taïwe, INSERM U836, Calcium Channels, Functions and Pathologies, Grenoble Institute of Neurosciences, Université Joseph Fourier, Chemin Fortuné Ferrini, Site Santé de La Tronche, P.O. Box 170, 38042 Cedex 9, Grenoble, France Tel: (+33) $0456520568,(+237) 77718670$ Fax: (+33) 0456520637 
extremities and for pain in legs and arms. A decoction of the roots has also been reported to be useful in relieving bronchitis and the attendant fever (Arbonnier, 2000). According to Cameroonian traditional healers, the plant is also effective in cases of cerebral deficit and behavioral disturbances in mentally-retarded children. Behavioral studies have revealed that Nauclea latifolia extract decreases spontaneous motor activity and exploratory behavior in mice, increases pentobarbital-induced sleep time in rats and attenuates the intensity of apomorphineinduced stereotypies in mice (Amos et al., 2005). Significant, anticonvulsant, anxiolytic and sedative activity of the decoction of the roots of Nauclea latifolia have already been reported from this laboratory (Ngo-Bum et al., 2009).

Here, we report the behavioral activity of the decoction of the roots of Nauclea latifolia on different experimental models, by using in vivo paradigms (forced swimming test, horizontal wire test and hole-board test) for detecting antidepressant, myorelaxant and anti-anxiety properties. The hole-board test (Takeda et al., 1998) was used to examine the possible interactions of Nauclea latifolia extract with anxiogenic agents, $N$-methyl- $\beta$-carboline-3-carboxamide (FG7142; a partial inverse agonist at the benzodiazepine site of the $\mathrm{GABA}_{\mathrm{A}}$ receptor complex), flumazenil (RO151788; the central benzodiazepine receptor antagonist) and bicuculline (a light-sensitive competitive antagonist of $\mathrm{GABA}_{\mathrm{A}}$ receptors). Additionally, the relationship between the neuropharmacological action of Nauclea latifolia extract and changes in GABA concentration in the brain were examined.

\section{MATERIALS AND METHODS}

Plant material: The roots of Nauclea latifolia used in this study were collected in the dry season (March 2007) from the National Park of Benoué (North-Cameroon). Botanical identification was performed at the National Herbarium, Yaoundé. Voucher herbarium specimen NO 20144/SRF/Cam has been deposited at the Yaoundé herbarium.

Preparation of extract: The bark of dried roots of Nauclea latifolia was ground. The powder $(1 \mathrm{~kg})$ was macerated in $5 \mathrm{~L}$ of distilled water for $1 \mathrm{~h}$. This mixture was boiled for $20 \mathrm{~min}$. After it cooled, the supernatant (decoction) was collected and filtered with Whatman No. 1 filter paper. The resulting extract was concentrated using a rotavapor at a temperature $70^{\circ} \mathrm{C}$ to obtain $81 \mathrm{~g}$ to yield an equivalent of $8.1 \%$ yield of the starting material. The decoction was administered orally (p.o.) $1 \mathrm{~h}$ before the test. The following doses were used: $16,40,80,160$ and $360 \mathrm{mg} \mathrm{kg}^{-1}$.

Chemical characterization: A few chemical studies of Nauclea latifolia have indicated the presence of Naucleamides A-E, a new monoterpene indole alkaloids (Shigemori et al., 2002), flavonoids, saponins, tannins, glycosides, cardiac glycosides, anthraquinones and phenols in the Nauclea latifolia extracts (Ngo-Bum et al., 2009).

Experimental animals: Adult male and female mice (Mus musculus Swiss; 20-25 g) were used throughout these studies. The animals were housed in standard cages at $25^{\circ} \mathrm{C}$ on a $12 \mathrm{~h}$ light-dark cycle. They were supplied with food and water ad libitum. The experiments were carried out in accordance with the National Ethical Committee Guidelines ( $\mathrm{N}^{\circ}$ FWA-IRB00001954) and International (EEC Council Directive 86/609, OJ L 358, 1, Dec. 12, 1987; Guide for the Care and Use of Laboratory Animal, US National Research Council) for the care and used of laboratory animals. All efforts were made to minimize both the suffering and number of animals used.

Drugs and chemicals: Drugs used for pharmacological interventions were: fluoxetine, diazepam (Sanofi-Synthelabo), N-methyl-ß-carboline-3-carboxamide (FG7142; Research Biochemicals, USA), flumazenil (F. Hoffmann-La Roche Ltd., Switzerland) and bicuculline (Sigma Aldrich Co., St. Louis, MO, USA). All other chemicals and reagents used in the brain GABA content estimation were from Sigma Aldrich Co., St. Louis, MO. Fluoxetine and diazepam were dissolved in distilled water. FG7142, flumazenil and bicuculline were prepared in the form of suspensions using a few drops of tween 80 and diluted with distilled water. All treatments were administered in a volume of $10 \mathrm{~mL} \mathrm{~kg}^{-1}$ mice body weight.

\section{Pharmacological tests}

Forced swimming test: Experiments were performed according to the methodology originally described by Porsolt et al. (1978) with minor modifications. On the first day of the experiments (pre test session), mice were individually placed into cylindrical recipients (diameter $10 \mathrm{~cm}$, height $25 \mathrm{~cm}$ ) containing $19 \mathrm{~cm}$ of water at $25 \pm 1^{\circ} \mathrm{C}$. The animals were left to swim for $15 \mathrm{~min}$ before being removed, dried and returned to their cages. The procedure was repeated $24 \mathrm{~h}$ later, in a $6 \mathrm{~min}$ swim session (test session). During both the pre test and the test sessions, a trained observer recorded the following behavioral responses: immobility (time spent floating with the minimal movements to keep the head above the 
water); swimming (time spent with active swimming movements); and climbing (time spent with upward movements of the forepaws directed to the cylinder wall). The animals were treated with Nauclea latifolia extract (16, 40, 80 and $160 \mathrm{mg} \mathrm{kg}^{-1}$, p.o.), the classical antidepressant fluoxetine $\left(10 \mathrm{mg} \mathrm{kg}^{-1}\right.$, i.p.) or distilled water $\left(10 \mathrm{~mL} \mathrm{~kg}^{-1}\right.$, p.o.) at 23,5 and $1 \mathrm{~h}$ before the $6 \mathrm{~min}$ testing session. An observer, blind to the treatments, analyzed all the experiments.

Horizontal wire test: Horizontal wire test was carried out by treating the mice with Nauclea latifolia extract $(16,40$, 80 or $160 \mathrm{mg} \mathrm{kg}^{-1}$, p.o. $)$, distilled water $\left(10 \mathrm{~mL} \mathrm{~kg}^{-1}\right.$, p.o.) or diazepam ( $1 \mathrm{mg} \mathrm{kg}^{-1}$, i.p.) using a slight modification of described an earlier method (Bonetti et al., 1982). Briefly, mice were lifted by the tail and allowed to grasp a horizontally strung wire $(1 \mathrm{~mm}$ diameter, $15 \mathrm{~cm}$ long and $20 \mathrm{~cm}$ above a table surface) with their forepaws and then released. The number of mice in each treatment group that did not grasp the wire with forepaws or actively grasped the wire with at least one hind paw within a $10 \mathrm{sec}$ period was recorded. Animals who failed to do it within $10 \mathrm{sec}$ were considered to have failed the test and this was considered as positive for a myorelaxant effect (Vogel and Vogel, 1997).

Hole-board test: The hole-board apparatus consisted of a gray wooden box $(40 \times 40 \mathrm{~cm}, 2.2 \mathrm{~cm}$ thick) with 16 equidistant holes $3 \mathrm{~cm}$ in diameter in the floor. Animals were transported to the dimly lit laboratory used for this test at least $1 \mathrm{~h}$ before testing. Mice were treated with Nauclea latifolia extract $\left(16,40,80,160\right.$ and $320 \mathrm{mg} \mathrm{kg}^{-1}$, p.o.), diazepam (0.5 and $1 \mathrm{mg} \mathrm{kg}^{-1}$, i.p.) or distilled water (10 $\mathrm{mL} \mathrm{kg}^{-1}$, p.o.) $1 \mathrm{~h}$ prior to testing. Each animal was placed singly in the center of the board facing away from the observer and its behavior recorded for $5 \mathrm{~min}$; the number of head-dips and rearing on the hole-board were counted for $5 \mathrm{~min}$. The latency to the first head-dip was measured using a stopwatch (File and Pellow, 1985). The duration of rearing, head-dip and spontaneous movements (number of squares crossed with all four paws) were also recorded (Takeda et al., 1998). In the antagonistic experiment, FG 7142 (5 and $10 \mathrm{mg} \mathrm{kg}^{-1}$, i.p.), flumazenil ( 3 and $4 \mathrm{mg} \mathrm{kg}^{-1}$, i.p.) and bicuculine (2.5 and $5 \mathrm{mg} \mathrm{kg}^{-1}$ ) were administered $30 \mathrm{~min}$ before the test. The mice received Nauclea latifolia extract $\left(160 \mathrm{mg} \mathrm{kg}^{-1}\right), 1 \mathrm{~h}$ before the test.

Brain GABA content estimation: The brain GABA level was estimated in groups of mice. The measurement of GABA, based on the method of Lowe et al. (1958) was carried out as follows. Animals were killed by decapitation at predetermined intervals after the administration of the Naucle latifolia extract $\left(16,40,80\right.$ and $160 \mathrm{mg} \mathrm{kg}^{-1}$, p.o.) or the distilled water $\left(10 \mathrm{~mL} \mathrm{~kg}^{-1}\right.$ p.o. $)$. The brains were rapidly removed, blotted, weighed and taken in ice cold $5 \mathrm{~mL}$ trichloroacetic acid $(10 \% \mathrm{w} / \mathrm{v})$, homogenized and centrifuged at $10000 \mathrm{~g}$ for $10 \mathrm{~min}$ at $0^{\circ} \mathrm{C}$. A sample $(0.1 \mathrm{~mL})$ of tissue extract was taken in $0.2 \mathrm{~mL}$ of $0.14 \mathrm{M}$ ninhydrin solution in $0.5 \mathrm{M}$ carbonate-bicarbonate buffer ( $\mathrm{pH} 9.9$ ), was kept in a water bath at $60^{\circ} \mathrm{C}$ for $30 \mathrm{~min}$ then cooled and treated with $5 \mathrm{~mL}$ of copper tartrate reagent $(0.16 \%$ disodium carbonate and $0.03 \%$ copper sulphate and $0.0329 \%$ tartaric acid). After $10 \mathrm{~min}$, the fluorescence reading was taken at $377 / 451 \mathrm{~nm}$ in a spectrofluorimeter. For GABA standards, different amounts $(20,40,60,80$, $100 \mu \mathrm{g}$ ) mixed with $1.5 \mu \mathrm{Mglutamic}$ acid were dissolved in $0.1 \mathrm{~mL} 10 \%$ trichloroacetic acid $(\mathrm{w} / \mathrm{v})$. GABA was determined by the measurement of the formed fluorescent product resulting from the reaction of GABA with ninhydrin in an alkaline medium, in the presence of glutamate (Sutton and Simmonds, 1974). The GABA content in brain was expressed in $\mu \mathrm{g} \mathrm{g}^{-1}$ of wet brain tissue.

Data analysis: Data obtained were expressed as Mean \pm SEM per group. Statistical differences between control and treated groups were tested by two-way ANOVA, followed by Tukey (HSD) as the post-hoc test (Frye, 2007). The differences were considered significant at $\mathrm{p}<0.05$. The statistical package used for the analysis was XL Stat 2007.

\section{RESULTS}

Antidepressant-like activity of Nauclea latifolia extract in the forced swimming test: The effects of Nauclea latifolia extract and fluoxetine on active behaviors in the forced swimming test are shown in Fig. 1. The ANOVA revealed significant effects of treatment on immobility $\left(\mathrm{F}_{5,41}=141.97 ; \quad \mathrm{p}<0.001\right)$, swimming behavior $\left(\mathrm{F}_{5,41}=129.41 ; \quad \mathrm{p}<0.0001\right)$ and climbing behavior $\left(\mathrm{F}_{5,41}=201.04 ; \mathrm{p}<0.001\right)$. Tukey's post hoc analysis demonstrated that all doses of Nauclea latifolia decoction that were administrated, significantly shortened the immobility time in comparison to negative control values. This effect was accompanied by a significant increase in swimming behavior $\left(\mathrm{F}_{5,41}=129.41\right.$; $\left.<0.0001\right)$, without modifying climbing behavior. Also, fluoxetine significantly decreased the immobility time during the 6 min test session while inducing corresponding increase in swimming and climbing behaviors, respectively. There was no significant difference between the effect of Nauclea latifolia extract and that observed after fluoxetine on the immobility time. 
Myorelaxant effects of Nauclea latifolia extract in the horizontal wire test: The oral administration of Nauclea latifolia extract or diazepam showed several changes after $1 \mathrm{~h}$ treatment and had the tendency to increase significantly the percentage of impaired mice $\left(\mathrm{F}_{5,53}=96.82 ; \mathrm{p}<0.001\right)$. The extract increase the number of impaired mice in a dose-dependent manner (at the doses of $16,40,80$ and $160 \mathrm{mg} \mathrm{kg}^{-1}$ ), resulting in 40,50, 50 and $60 \%$ impaired increases, respectively. The percentage of impaired mice was also significantly increased $\left(\mathrm{F}_{5,53}=74.18 ; \mathrm{p}<0.001\right)$ at $70 \%$ for treatment with diazepam. The effect of Nauclea latifolia at the doses of $80 \mathrm{mg} \mathrm{kg}^{-1}$ appeared to be more potent than diazepam after $50 \mathrm{~min}$ treatment in the study (Fig. 2).
Effect of Nauclea latifolia extract on exploratory behavior of mice in the hole-board test: Nauclea latifoliatreated mice manifested significant dose-dependent increases in both the number $\left(\mathrm{F}_{7,38}=53.65 ; \mathrm{p}<0.001\right)$ and duration $\left(\mathrm{F}_{7,38}=142.14 ; \mathrm{p}<0.0001\right)$ of head-dips and dose-dependent decrease in the latency to the first head-dips $\left(\mathrm{F}_{7,38}=111.94 ; \mathrm{p}<0.001\right)$ in the hole-board system at 40,80 and $160 \mathrm{mg} \mathrm{kg}^{-1}$. Also, the extract significantly reduced in dose-dependent manner the total locomotor activity $\left(\mathrm{F}_{7,38}=177.93 ; \mathrm{p}<0.0001\right)$, the number $\left(\mathrm{F}_{7,38}=157.86 ; \mathrm{p}<0.0001\right)$ and duration $\left(\mathrm{F}_{7,38}=103.87 ; \mathrm{p}<0.0001\right)$ of rearing and head-dipping. Diazepam produced the same effect as Nauclea latifolia extract. This compound produced a dose-dependent

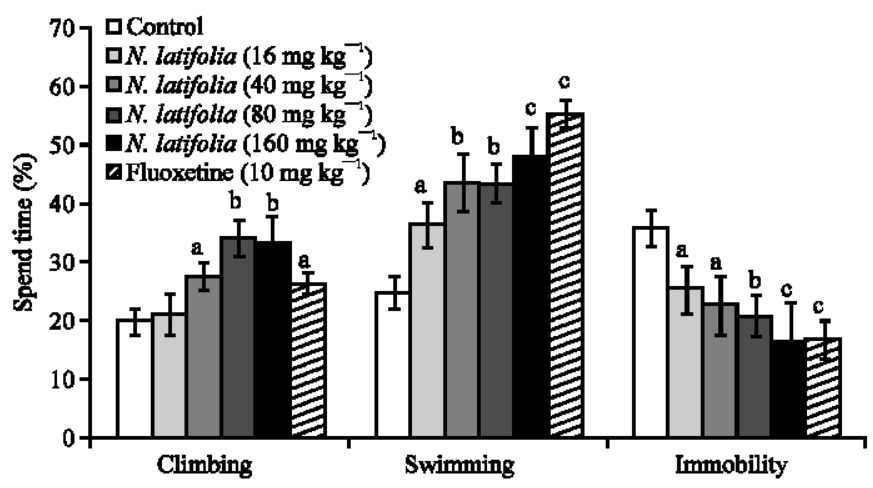

Fig. 1: Effects of acute Nauclea latifolia extract $\left(16,40,80\right.$ and $\left.160 \mathrm{mg} \mathrm{kg}^{-1}\right)$ or fluoxetine $\left(10 \mathrm{mg} \mathrm{kg}{ }^{-1}\right)$ treatment on active behaviors in the forced swimming test in mice. Data represent the percentage of the duration of climbing, swimming and immobility during the $6 \mathrm{~min}$ test session. Comparisons were made by using a two-way ANOVA followed Tukey's (HSD) test, ${ }^{a} \mathrm{p}<0.05,{ }^{b} \mathrm{p}<0.01,{ }^{c} \mathrm{p}<0.001$, compared with control group ( $\mathrm{n}=8$ animals per group)

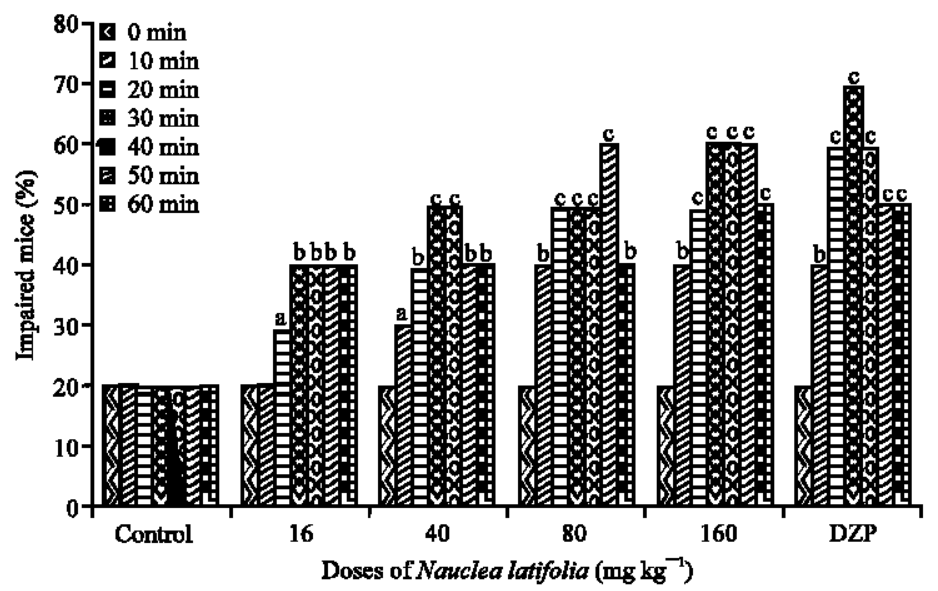

Fig. 2: Effects of acute Nauclea latifolia extract $\left(16,40,80\right.$ and $\left.160 \mathrm{mg} \mathrm{kg}^{-1}\right)$ or diazepam $\left(1 \mathrm{mg} \mathrm{kg}^{-1}\right)$ treatment on percentage of impaired mice in horizontal wire test. ${ }^{2} \mathrm{p}<0.05,{ }^{b} \mathrm{p}<0.01,{ }^{c} \mathrm{p}<0.001$, significantly different compared to the control group, data were analysis by two-way ANOVA, followed Tukey's (HSD) multiple comparison test $(\mathrm{n}=10$ animals per group) 

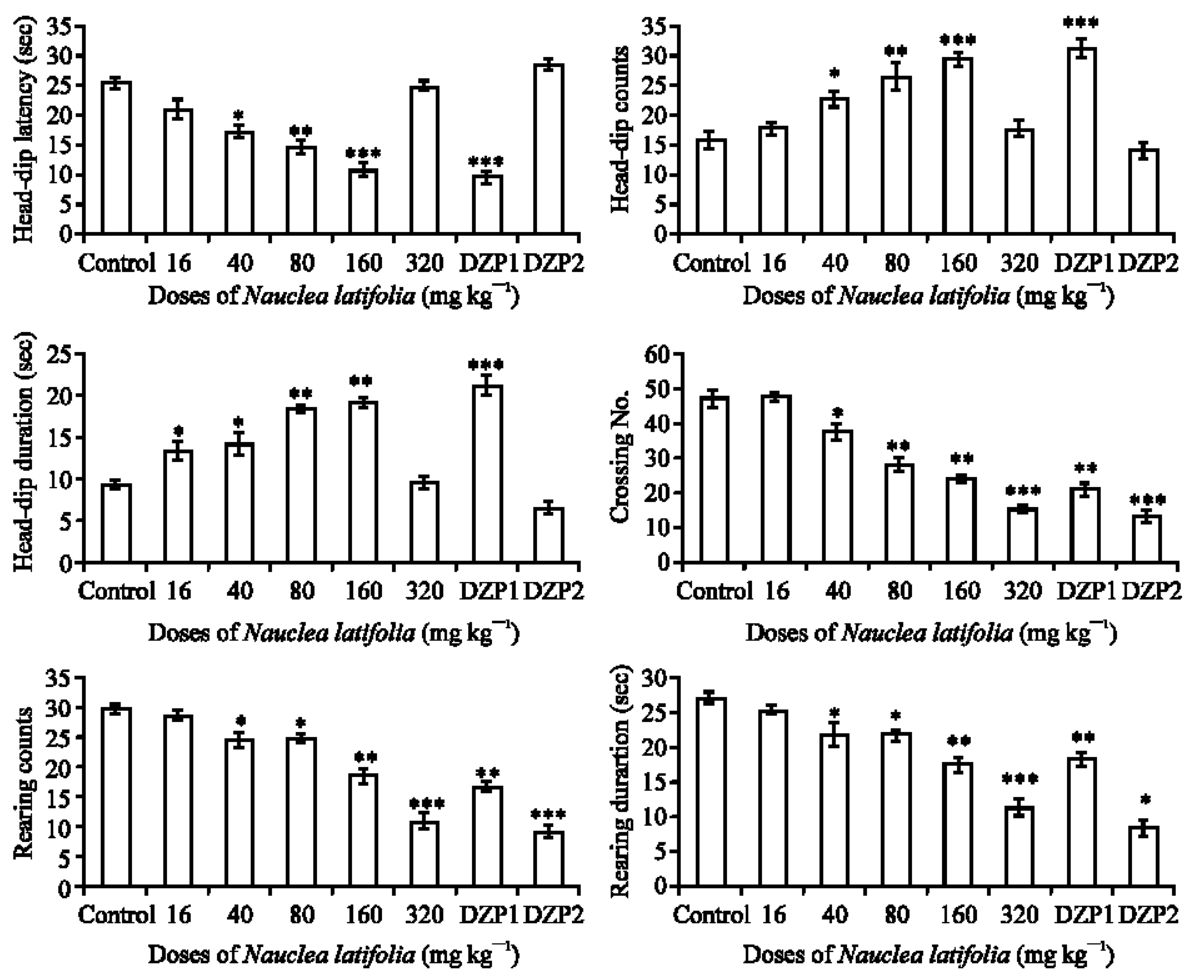

Fig. 3: Effects of acute Nauclea latifolia extract $\left(16,40,80,160\right.$ and $\left.320 \mathrm{mg} \mathrm{kg}^{-1}\right)$ or diazepam (DZP1: $0.5 \mathrm{mg} \mathrm{kg}^{-1}$; DZP2: $1 \mathrm{mg} \mathrm{kg}^{-1}$ ) on the head-dip latency, head-dip count, head-dip duration, crossing number, rearing counts and rearing duration in the hole-board test. ${ }^{*} \mathrm{p}<0.05,{ }^{* *} \mathrm{p}<0.01,{ }^{* * *} \mathrm{p}<0.001$, significantly different compared to the control, data were analysis by two-way ANOVA, followed Tukey's (HSD) multiple comparison test ( $\mathrm{n}=6$ animals per group)

decrease in locomotor activity as well as in the number and duration of rearing behaviors and an increase in the number and duration of head-dips. This difference was statistically significant $\left(\mathrm{F}_{7,38}=96.15 ; \mathrm{p}<0.0001\right)$ (Fig. 3).

Effect of Nauclea latifolia extract $\left(160 \mathrm{mg} \mathrm{kg}^{-1}\right)$ and its modification by FG7142, flumazenil and bicuculline on exploratory behavior activity of mice in the hole-board test: To determine whether the behavioral effect of Nauclea latifolia is exerted via the GABAergic nervous system, mice-treated with Nauclea latifolia extract were co-treated with FG7142 (a partial inverse agonist at the benzodiazepine site of the $\mathrm{GABA}_{\mathrm{A}}$ receptor complex), flumazenil (a central benzodiazepine receptor antagonist) or bicuculline (a $\mathrm{GABA}_{\mathrm{A}}$ receptor antagonist). Co-treatment with FG7142 appreciably blocked the Nauclea latifolia-induced increase in head dips number $\left(\mathrm{F}_{6,33}=143.76 ; \mathrm{p}<0.0001\right)$ and durations $\left(\mathrm{F}_{6,33}=142.14 ; \mathrm{p}<0.0001\right)$ in the hole-board system. Co-treatment with flumazenil or bicuculline significantly attenuated Nauclea latifolia-induced increase in head dips number and durations in the same system. In
Table 1: Effect of the Nauclea latifolia extract on brain GABA content in mice

\begin{tabular}{lccc}
\hline Treatments & Dose $\left(\mathrm{mg} \mathrm{kg}^{-1}\right)$ & $\begin{array}{l}\text { GABA level in } \\
\text { brain tissue }\left(\mu \mathrm{g} \mathrm{g}^{-1} \pm \mathrm{SEM}\right)\end{array}$ & Increase (\%) \\
\hline Control & - & $391.5 \pm 0.7$ & \\
N. latifolia & 16 & $404.7 \pm 3.3$ & 3.3 \\
N. latifolia & 40 & $418.2 \pm 6.4$ & 6.4 \\
N. latifolia & 80 & $440.2 \pm 11.0^{*}$ & 11.0 \\
N. latifolia & 160 & $484.7 \pm 19.2^{* *}$ & 19.2 \\
\hline
\end{tabular}

Results are expressed as Mean \pm SEM and units are in $\mu \mathrm{g} \mathrm{g}^{-1}$, GABA level in brain tissue. ${ }^{*} \mathrm{p}<0.05, * * \mathrm{p}<0.01$ significantly different compared to the control group, data were analysis by two-way ANOVA, followed Tukey's (HSD) multicomparaison test ( $\mathrm{n}=6$ animals per group)

addition, the latency to head-dipping tended to increase following treatment with FG7142, flumazenil and bicuculline. However, the number of crossing and rearing were not effectively blocked by FG7142, flumazenil and bicuculline at the doses of 5,2 and $2.5 \mathrm{mg} \mathrm{kg}^{-1}$, respectively (Fig. 4).

Effect of Nauclea latifolia extract on brain GABA content: A significant increase $\left(\mathrm{F}_{4,29}=72.6 ; \mathrm{p}<0.01\right)$ in the level of brain GABA concentration in animals treated with Nauclea latifolia extract was observed (Table 1). 

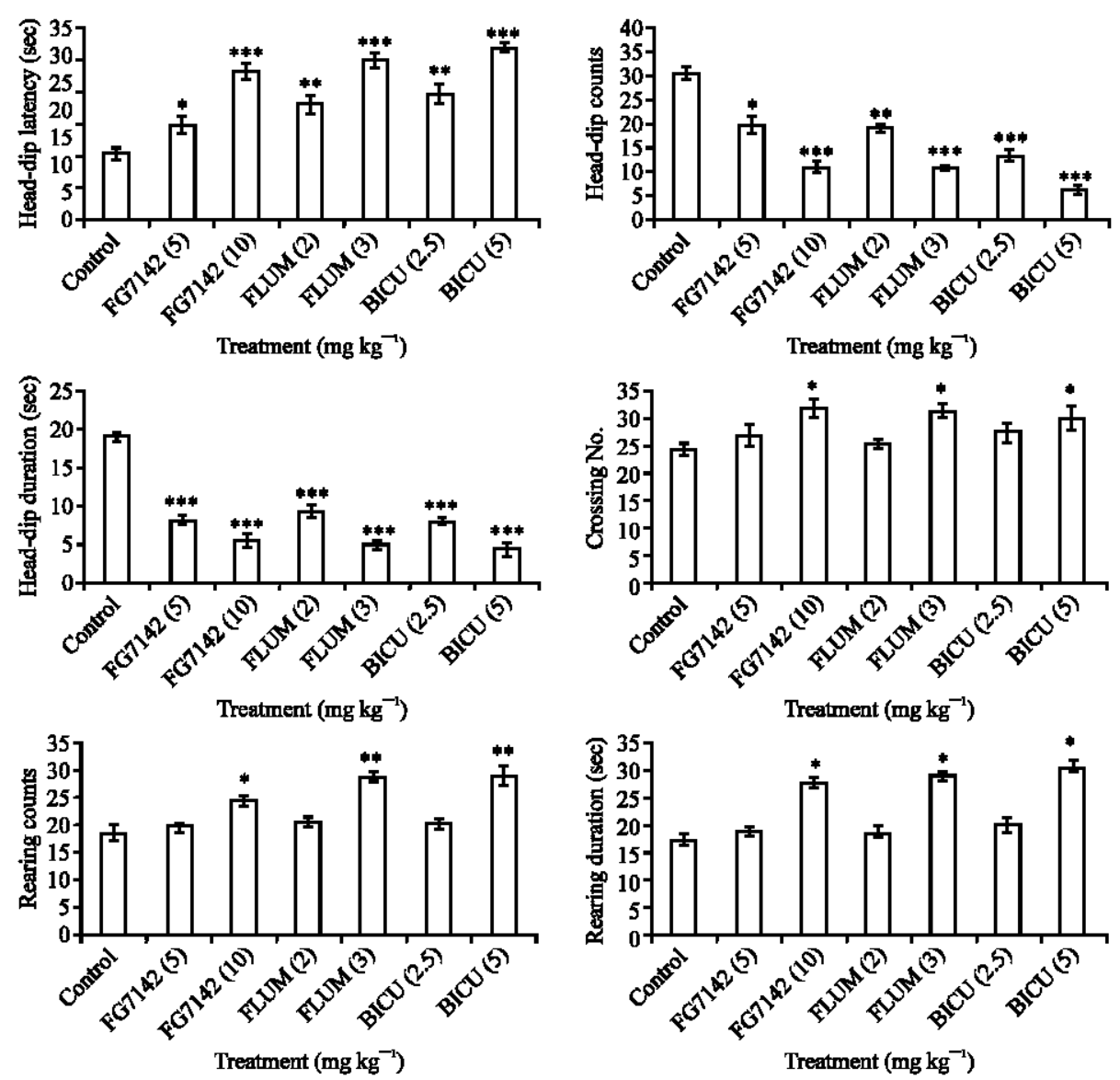

Fig. 4: Effect of acute Nauclea latifolia extract $\left(160 \mathrm{mg} \mathrm{kg}^{-1}\right)$ treatment $30 \mathrm{~min}$ after pretreatment with FG71 42 (5 and $10 \mathrm{mg} \mathrm{kg}^{-1}$ ), flumazenil (FLUM; 2 and $3 \mathrm{mg} \mathrm{kg}^{-1}$ ) or bicuculline (BICU; 2.5 and $5 \mathrm{mg} \mathrm{kg}^{-1}$ ) on the head-dip latency, head-dip count, head-dip duration, crossing number, rearing counts and rearing duration in the hole-board test. ${ }^{*} \mathrm{p}<0.05,{ }^{* *} \mathrm{p}<0.01,{ }^{* * *} \mathrm{p}<0.001$, significantly different compared to the control, data were analysis by two-way ANOVA, followed Tukey's (HSD) multiple comparison test ( $\mathrm{n}=6$ animals per group)

\section{DISCUSSION}

The results of the present series of experiments show that Nauclea latifolia extract displays a behavioral profile that is consistent with an anxiolytic-, myorelaxant- and antidepressant-like action.

The forced swimming in rodents is an accepted behavioral test that is believed to predict the clinical efficacy of many types of antidepressant treatments (Porsolt et al., 2001; Butterweck et al., 1998). Nauclea latifolia extract caused a dose-dependent reduction in the percentage of duration of immobility time using antidepressant screens while having significant effects on the power of the movements. Similar results were obtained by Porsolt et al. (1978) and Steru et al. (1985) indicating antidepressant properties of this extract. The effects of Nauclea latifolia extract were comparable to those observed with the reference antidepressants, fluoxetine. Numerous studies have demonstrated that antidepressant drugs, including fluoxetine, facilitated the action of serotonine. It was also demonstrated that the swimming behavior was sensitive to serotoninergic compounds, such as the selective serotonin reuptake inhibitor fluoxetine, whereas, the climbing behavior was sensitive to drugs that selectively affect the noradrenergic transmission (Detke et al., 1995; Abiodun et al., 2007).

The potential to impair psychomotor functions is one of the most common side effects of widely-used sleep aids (Aktories et al., 2005). To verify the effect of our extract on muscle strength we used the horizontal wire test in mice. The extract showed dose-dependent myorelaxant activity. Against the background that enhanced GABAergic transmission, the known mechanism for benzodiazepines, is associated with a loss of muscle 
strength, these findings suggest that Nauclea latifoliainduced central nervous system-related effects might be caused by interference with the $\mathrm{GABA}_{\mathrm{A}}$ receptor. Benzodiazepines are known to facilitate GABA activate on of $\mathrm{GABA}_{\mathrm{A}}$ receptor's intrinsic $\mathrm{Cl}^{-}$channel and, in turn, to facilitate inhibitory neurotransmission (Evans and Lowry, 2007; Ngo-Bum et al., 2009). This is manifested as an increase in the frequency of ion channel opening in response to GABA. Earlier reports have showed that the plant does not attenuate motor coordination (rota-rod performance) suggesting that actions may not be achieved via neuromuscular blockade (Amos et al., 2005). Rather, the effects might involve neurons that control central depressant activities.

The hole-board test provides a simple method for measuring the response of an animal to unfamiliar environment and it is widely used to assess emotionality, anxiety and/or responses to stress in animal (Nolan and Parkes, 1973; Takeda et al., 1998). Anxiolytic-like effects of Nauclea latifolia have previously been observed by Ngo-Bum et al. (2009). These researchers showed that the decoction of Nauclea latifolia roots are active in the elevated plus maze paradigm. Additionally, several observations indicate an efficacy of Nauclea latifolia preparations in the treatment of anxiety and stress-related symptoms. The present data demonstrate that Nauclea latifolia extracts have clear and consistent effects on head-dipping behavior in the hole-board test. Both the number and the duration of exploratory head-dips were dose-dependently increased by treatment with either compound at doses that did not produce sedation. This observation is consistent with previous reports of an increase in the frequency and duration of exploratory head-dips exhibited on a hole-board following the injection of non-sedative doses of diazepam (Takeda et al., 1998). However, this effect was reversed at high doses of diazepam, which induced sedation (Suzuki et al., 1990). These results demonstrate that Nauclea latifolia extract has a good anxiolytic-like effect without a stimulating head-dipping behavior and reduction of locomotor activity in the hole-board.

In addition, to determine which neurotransmitter system is involved in the anxiolytic-like properties of Nauclea latifolia extract, specific $\mathrm{GABA}_{\mathrm{A}}$ receptor antagonists were introduced in the hole-board test. Increased number and duration of head-dips in the holeboard test induced by Nauclea latifolia extract were antagonized by $N$-methyl- $\beta$-carboline-3-carboxamide, flumazenil and bicuculline. These results indicate that the effects are mainly mediated via the GABAergic system (Evans and Lowry, 2007; Woode et al., 2010).
Anxiolytics (e.g., diazepam) are known to exert their pharmacological action by causing an increase in GABA content in mice cerebral hemisphere (Saad, 1972). It was found that Nauclea latifolia significantly enhanced the brain GABA concentration which again is suggestive of an anxiolytic action of the roots decoction. Taken together, we suggest that the behavioral action of Nauclea latifolia extract is correlated to an increase in GABA concentrations in the brain. These results suggest that the mechanism of Nauclea latifolia extract is related in part to the highly sensitive benzodiazepine site of the GABA-benzodiazepine receptor chloride ionophore complex (Hashimoto et al., 2006).

In conclusion, our results provide evidence that Nauclea latifolia roots decoction exert myorelaxant, antidepressant and anxiolytic effects in mice. However, further studies are necessary to confirm and extend these results. These, findings are relevant by contributing to our understanding of the traditional medical uses of this plant.

\section{ACKNOWLEDGMENTS}

This research was supported by Grant from the Agence Universitaire de la Francophonie (Bourse Internationale de Formation à la Recherche Doctorale, AUF 2009/2010, Ref.: 1021FR/277/BAC 2009/JGZ/AS) for valuable financial assistance and University of Ngaoundéré-Cameroon. We thank Agence Universitaire de la Francophonie (AUF) for a fellowship application to Germain Sotoing Taïwe.

\section{REFERENCES}

Abiodun, F., A. Igwe and O. Osahon, 2007. Anti-microbial evaluation of a herbal dental remedy stem bark of Nuclea latifolia-family rubiaceae. J. Applied Sci., 7 : 2696-2700.

Aktories, K., U. Förstermann, F. Hofmann and K. Starke, 2005. Allgemeine und Spezielle Pharmakologie und Toxikologie. Elsevier GmbH, München.

Amos, S., J. Abbah, B. Chindo, I. Edmond and L.B. Binda et al., 2005. Neuropharmacological effects of the aqueous extract of Nauclea latifolia root bark in rats and mice. J. Ethnopharmacol., 97: 53-57.

Arbonnier, M., 2000. Arbres, Arbustes et Lianes des Zones Sèches d'Afrique de l'Ouest. 1st Edn., CIRAD Publishers, Paris, ISBN: 2-87614-431-X, pp: 541.

Bonetti, E.P., L. Pieri, R. Cumin, R. Schaffner and M. Pieri et al., 1982. Benzodiazepine antagonist Ro 15-1788: Neurological and behavioral effects. Psychopharmacology, 78: 8-18. 
Buller, R. and V. Legrand, 2001. Novel treatments for anxiety and depression: Hurdles in bringing them to the market. Drug Discov. Today, 6: 1220-1230.

Butterweck, V., F. Petereit, H. Winterhoff and A. Nahrstedt, 1998. Solubilized hypericin and pseudohypericin from Hypercum perforatum exert antidepressant activity in the forced swimming test. Planta Med., 64: 291-294.

Detke, M.J., M. Rickels and I. Lucki, 1995. Active behaviors in the rat forced swimming test differentially produced by serotoninergic and noradrenergic antidepressants. Psychopharmacology, 121: 66-72.

Evans, A.K. and C.A. Lowry, 2007. Pharmacology of the $\beta$-carboline FG 7142, a partial inverse agonist at the benzodiazepine allosteric site of the $\mathrm{GABA}_{\mathrm{A}}$ receptor: Neurochemical, neurophysiological and behavioral effects. CNS Drug Rev., 13: 475-501.

File, S.E. and S. Pellow, 1985. The effects of triazolobenzodiazepines in two anima tests of anxiety and in the holeboard. Br. J. Pharmacol., 86: 729-735.

Frye, C., 2007. Excel 2007 Pocket Guide. 2nd Edn., O'Reilly Media Inc., USA., ISBN-10: 0-596-51452-2.

Hashimoto, Y., H. Araki, K. Suemaru and Y. Gomita, 2006. Effects of drugs acting on the GABA-benzodiazepine receptor complex on flurothyl-induced seizures in Mongolian gerbils. Eur. J. Pharmacol., 536: 241-247.

Lowe, I.P., E. Robins and G.S. Eyermen, 1958. The fluorimetric measurement of glutamic decarboxylase and its distribution in brain. J. Neurochem., 3: 8-16.

Ngo-Bum, E., G.S. Taiwe, F.C.O. Moto, G.T. Ngoupaye and G.C.N. Nkantchoua et al., 2009. Anticonvulsant, anxiolytic and sedative properties of the roots of Nauclea latifolia Smith in mice. Epilepsy Behav., 15: 434-440.

Nolan, N.A. and M.W. Parkes, 1973. The effects of benzodiazepines on the behavior of mice on holeboard. Psychopharmacologia, 29: 277-286.

Porsolt, R.D., G. Anton, N. Blavet and M. Jalfre, 1978. Behavioral despair in rats: A new model sensitive to antidepressant treatments. Eur. J. Pharmacol., 47: $379-391$.
Porsolt, R.D., G. Brossard, C. Hautbois and S. Roux, 2001. Rodent models of depression: Forced swimming and tail suspension behavioral despair tests in rats and mice. Curr. Protoc. Neurosci., Chapter 8: 8.10A-8.10A.

Saad, S.P., 1972. Administration of CNS depressant drugs like barbiturates, hydantoin and diazepam etc. can restore the isoniazid induced fall in brain GABA levels. J. Pharm. Pharmacol., 24: 839-840.

Shigemori, H., T. Kagata, H. Ishiyama, F. Morah, A. Ohsaki and J. Kobayash, 2002. Nucleamides A-E, new monotherpene indole alkaloids from Nauclea latifolia. Chem. Pharm. Bull., 51: 58-61.

Steru, L., R. Chermat, B. Thierry and P. Simon, 1985. The tail suspension test: A new method for screening antidepressants in mice. Psychopharmacol. (Berl.), 85: $367-370$.

Sutton, I. and M. Simmonds, 1974. Effects of acute and chronic pentobarbitone on the $\beta$-aminobutyric acid system in rat brain. Biochem. Pharmacol, 23: 1801-1808.

Suzuki, T., M. Inayama and M. Misawa, 1990. The effect of diazepam on exploratory behavior and its strain differences in inbred rats. Jap. J. Psychopharmacol., 10: 307-314.

Takeda, H., M. Tsuji and T. Matsumiya, 1998. Changes in head-dipping behavior in the hole-board test reflect the anxiogenic and/or anxiolytic state in mice. Eur. J. Pharmacol., 350: 21-29.

Vogel, H.G. and W.H. Vogel, 1997. Drug Discovery and Evaluation, Pharmacological Assays. 1st Edn., Springer, Berlin.

Woode, E., E.B. Gyasi, N. Amidu, C. Ansah and M. Duwiejua, 2010. Anxiolytic and antidepressant effects of a leaf extract of Palisota hirsute K. schum. (Commelinaceae) in mice. Int. J. Pharmacol., 6: 1-17.

Zhang, Z.J., 2004. Therapeutic effects of herbal extracts and constituents in animal models of psychiatric disorders. Life Sci., 75: 1659-1699. 